\title{
Histochemical evaluation of the lipid droplet content of bovine oviductal and endometrial epithelial cells
}

\author{
R. J. Wordinger*, J. F. Dickey and A. R. Ellicott \\ *Department of Biology, St Bonaventure University, St Bonaventure, New York, 14778, and \\ Departments of Dairy and Animal Science, Clemson University, Clemson, South Carolina 29631, U.S.A.
}

Limited histochemical information is available concerning the lipid content of the bovine oviduct (Weeth \& Herman, 1952; Bjorkman \& Fredricsson, 1961) and endometrium (Weeth \& Herman, 1952; Skjerven, 1956; Marinov \& Lovell, 1968), and the proximity of the corpus luteum or developing follicle has not been examined as a possible local influence on such content. The object of this study was to examine the influence of the stage of the oestrous cycle as well as the proximity of the corpus luteum or developing follicle on the histochemically demonstrable lipid of the bovine oviduct and endometrium.

Twenty Hereford and Angus heifers, 18-22 months of age, were observed twice daily for oestrus and only heifers exhibiting oestrous cycles of 18-22 days were used. The animals were killed at different stages of the oestrous cycle: oestrus $=$ Day 1 ; metoestrus $=$ Days $2-4$; dioestrus $=$ Days 5-18; pro-oestrus = Days 19-21. Tissue samples were obtained within 15 to $30 \mathrm{~min}$ of death and included the right and left ampullae $(2 \mathrm{~cm}$ from the infundibulum), isthmi $(1 \mathrm{~cm}$ from the uterotubal junction), and uterine horns ( $5 \mathrm{~cm}$ caudally from the uterotubal junction). Thesamples were placed on specimen holders and frozen in liquid nitrogen followed by cryostat sectioning at $-15^{\circ} \mathrm{C}$. Frozen sections, 10-15 $\mu \mathrm{m}$ thick, were attached to coverslips, stained with Oil Red O (Lillie, 1965), counterstained with Harris's haematoxylin, mounted on slides and observed with bright-field microscopy. Four sections of each tract sample were scored subjectively by one person on a scale from $0-4(0=$ no lipid, 4 = dense lipid).

The property of staining with oil-soluble dyes is generally referred to as sudanophilia, even though the name of the oil-soluble dye utilized may not include the word Sudan (Lillie, 1965). In keeping with this nomenclature, therefore, granules which stained with Oil Red $\mathrm{O}$ in this study are referred to as sudanophilic droplets.

Oviduct. Major differences were noted in the lipid content of the epithelial cells which lined the ampulla and isthmus. Moderate amounts (Table 1) were present in the isthmic epithelial cells, usually close to the nucleus, and were rarely seen in the apical part of the cell (PI. 1, Fig. 1). No difference was noted between ciliated and secretory epithelial cells. The stage of the oestrous cycle and the proximity of the CL or follicle had little effect on oviductal lipid content. The occasional droplets in the ampullary epithelial cells (Pl. 1, Fig. 2) were usually scattered in the apical cytoplasm and were found in secretory and ciliated cells.

Table 1. Influence of the oestrous cycle on the lipid content* of bovine reproductive tissue

\begin{tabular}{lcccc}
\hline & \multicolumn{3}{c}{ Stage of the oestrous cycle } \\
\cline { 2 - 5 } \multicolumn{1}{c}{ Tissue } & Oestrus & Metoestrus & Dioestrus & Pro-oestrus \\
\hline Ampullary epithelium & 0.25 & 0.25 & 0.20 & 0.30 \\
Isthmic epithelium & 1.85 & $2 \cdot 12$ & 2.20 & 2.40 \\
Endometrium, superficial glands & 2.00 & 1.25 & 2.75 & 1.85 \\
Endometrium, surface epithelium & 2.20 & 1.50 & 2.83 & 2.00 \\
\hline
\end{tabular}

* Lipid content was scored on an arbitrary scale from 0-4: each figure represents the mean score of 40 sections; 4 sections from the left and right sịdes of 5 animals, 
Contrary to the reports of Weeth \& Herman (1952) and Bjorkman \& Fredricsson (1961), these results demonstrate that distinct regional differences exist within the bovine oviduct with respect to cytoplasmic lipid content. There was no indication in this study that the lipid observed in the ampulla or isthmus was secreted into the lumen. The constant amount of lipid contained in the epithelial cells suggests that rather than being secreted for use by the embryo it may be utilized within the epithelial cells for metabolic needs. There is also the possibility that this material represents substances absorbed from the lumen.

Uterus. There were obvious variations in the amounts of sudanophilic droplets in the surface epithelial cells of the endometrium (Table 1). Heavy concentrations of droplets were present throughout the epithelium from Days 8 to 14 of the oestrous cycle (Pl. 1, Fig. 3), moderateamounts from Day 18 through oestrus, and lower amounts from Days 2-6. The epithelial cells of the superficial uterine glands followed the pattern of droplet content exhibited by the surface epithelial cells. The epithelial cells of deeper uterine glands (Pl. 1, Fig. 4) contained few, if any, sudanophilic droplets. The proximity of the CL or developing follicle had no localized effect with respect to the lipid content of the endometrial cells, as found by Cloud \& Casida (1969) for sheep endometrial samples.

These results indicate that cytoplasmic lipid of the surface and superficial glandular epithelial cells was subject to cyclic variations, as reported by Skjervin (1956) and Marinov \& Lovell (1968). The largest accumulation of sudanophilic droplets occurred in conjunction with the development of the corpus luteum. As the corpus luteum regressed and a new follicle presumably developed there was a diminution of lipid droplets in the epithelial cells, suggesting that progesterone and/or oestrogen controls the formation and/or storage of lipid within these cells.

Brinsfield \& Hawk (1973) found that administration of oestradiol to ewes after ovariectomy decreased the concentration of lipid droplets in the endometrial surface epithelial cells. Nilsson (1962) and Fuxe \& Nilsson (1963) have also shown that the administration of oestradiol to ovariectomized mice causes a decrease in the number of lipid droplets in the uterine epithelium. The function of this lipid is not clear. It may be secreted and play a role in embryo nutrition, or represent substances absorbed from the uterine lumen. The lipid may represent precursors of steroid hormones (Marinov \& Lovell, 1968) or be connected with prostaglandin synthesis by the endometrium (Brinsfield \& Hawk, 1973).

This paper is published with the approval of the Director of the Agriculture Experiment Station as Technical Contributor No. 1392. The excellent technical assistance of Elaine Holliday is gratefully acknowledged.

\section{References}

Buorkman, N. \& Fredricsson, B. (1961) The bovine oviduct epithelium and its secretory process as studied with the electron microscope and histochemical tests. Z. Zellforsch. mikrosk. Anat. 55, 500-513.

Brinsfield, T.H. \& Hawk, H.W. (1973) Control by progesterone of the concentration of lipid droplets in epithelial cells of the sheep endometrium. $J$. Anim. Sci. 36, 919-922.

Cloud, J.G. \& CAsidA, L.E. (1969) Histological changes in the uterine horns during the estrous cycle in the ewe in relation to the proximity of the corpus luteum. J. Anim. Sci. 28, 492-495.

Fuxe, K. \& Nilsson, O. (1963) The lipid granules of the uterine epithelium in the spayed mouse. $J$. Ultrastruct. Res. 8, 379-390.

LILLIE, R.D. (1965) Hiștopathologic Technique and
Practical Histochemistry, p. 454. McGraw Hill, New York.

Marinov, V. \& Lovell, J.E. (1968) Cytology of the bovine uterine epithelium during the estrous cycle. Am. J. vet. Res. 29, 13-30.

Nilsson, O. (1962) The effect of estrogen on the histology of the uterine epithelium of the mouse. 1. Electron microscopy of decomposing lipid granules. Expl Cell Res. 26, 334-343.

SkJERvin, O. (1956) Phosphatase, fat and carbohydrate content of normal bovine endometrium. Biopsy studies of cyclic variations. Fert. Steril. 7, 3137.

WeETH, H.J. \& Herman, H.A. (1952) A histological and histochemical study of the bovine oviducts, uterus and placenta. Res, Bull. Mo. agric. Exp. Stn 501, $1-54$. 
PLATF $]$
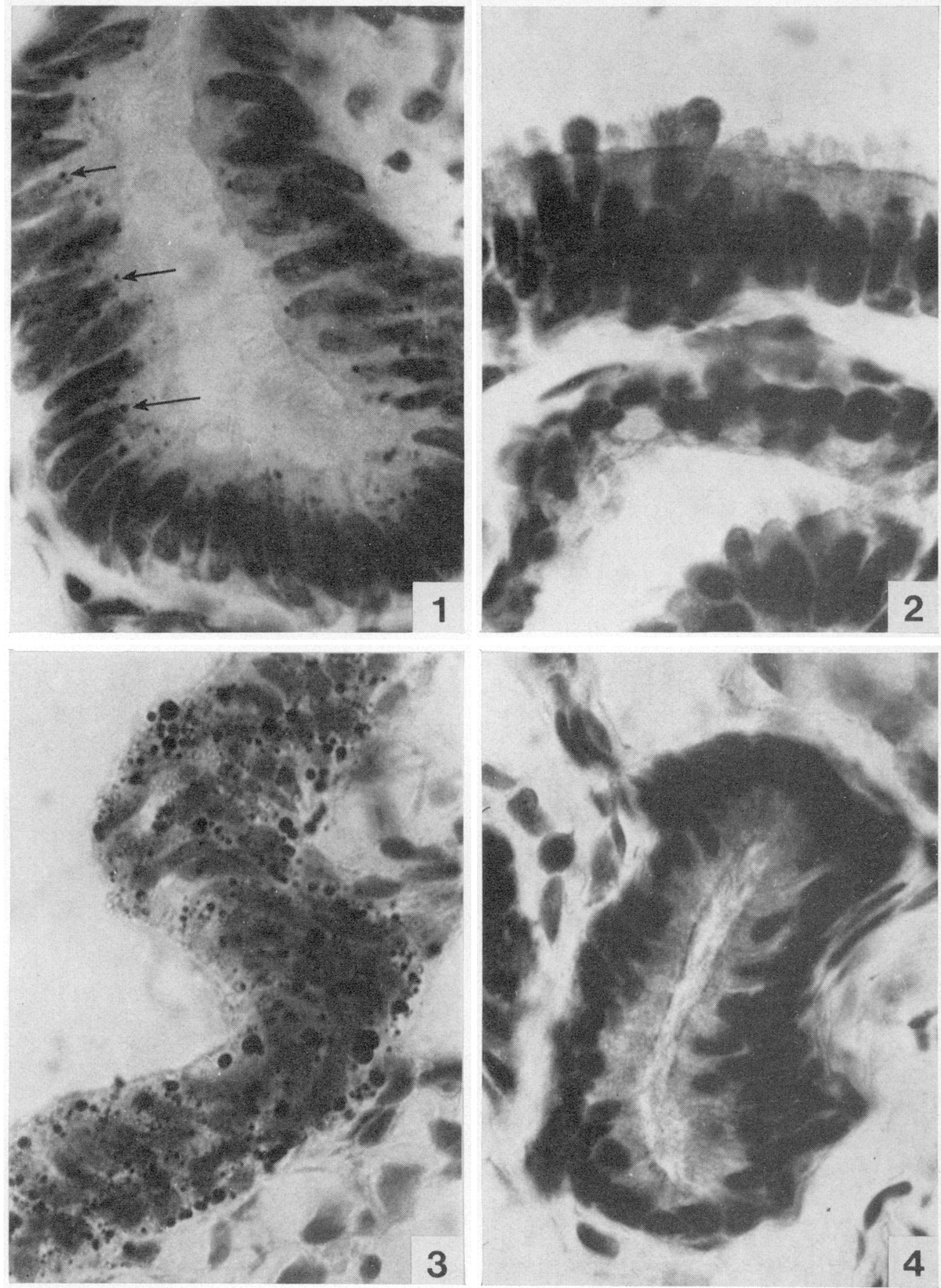

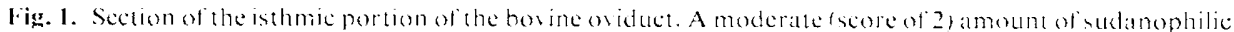
droplets is present. Oil Red $O, \times 980$.

Vig. 2. Section of the ampullary portion of the bosine oriduct. Fithelial eells and cellular extrusions are deroid of sudanophilic granules. Oil Red $0, \times 1024$

Fig. 3. Section of the surfice epithelial layer of the hovine endometrium on Day 14 of the oestrous crele. A healy fscore of 4 ) accumulation of sudanophitic droplets is evident. Oil Red $0 . \times 1056$.

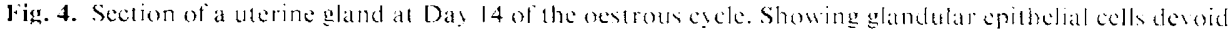
of sudanophilic dropless. Oil Red O, > iost. 